\section{New indication for an old anesthetic technique: could we consider now rapid sequence spinal anesthesia in a COVID-19 time?}

\section{To the Editor}

Coronavirus disease 2019 (COVID19), declared as a pandemic disease in March 2020, refers to a respiratory tract infection caused by the newly severe acute respiratory syndrome coronavirus 2. Anesthesiologists are at the front line in the management of surgical patients dealing with cases that are confirmed or suspected COVID-19. Procedures, such as bag mask ventilation, open airway suctioning or even endotracheal intubation/extubation, are known to be aerosol producers, putting at risk all healthcare professionals present at the operation room. ${ }^{1}$ Regional anesthesia, which is not automatically contraindicated in these patients, plays a prominent role in these cases since it reduces high-risk interventions, potential staff contamination, patients' recovery time and maximize the management and efficiency of the operating room times. ${ }^{1}$ Additionally, there is likely an optimization of respiratory function, which could be important due to this virus' tropism for the lung.

In obstetrics, regional anesthesia assumes even a greater role due to the benefits it brings to both mother and newborn. ${ }^{2}$ However, its medium time for preparation and execution could lead one to choose general anesthesia over regional in an emergency cesarean section (category 1 urgency): the median times (min:s) for spinal procedure, onset of spinal block and general anesthesia were 2:56, 5:56 and 1:56, respectively. ${ }^{3}$ The rapid sequence spinal technique was first described in 2003 as a new approach to the provision of spinal anesthesia for the most urgent obstetric cases. $^{2}$ It reduces both maternal morbidity and mortality and allows the parturient to be awake during the delivery. ${ }^{2}$ The rapid sequence spinal technique is a no-touch technique, which means performing a central neuraxial block without palpating anatomic landmarks previously. It should be performed by a specialist medical doctor and is possible to use only sterile gloves for barrier precautions. The starting of the surgical procedure occurs when sensorial block is equal to or greater than T10 and ascending. ${ }^{2}$ This technique implies a single spinal puncture unless obvious correction allows a second attempt and an immediate conversion to general anesthesia, if necessary. ${ }^{2}$ It should not be forgotten that, when opting for regional anesthesia, a pregnant woman should be alerted to the fact that she can undergo traction and stretching of the tissues by surgeons, without perceiving pain. Although the addiction of a lipophilic opioid reduces pain and discomfort for a given level of sensory block, the procedure should not be delayed if the drug cannot be rapidly available. ${ }^{2}$ If no opioid is added, the anesthesiologist should consider a higher dose of local anesthetic than standard, namely hyperbaric bupivacaine $0.5 \%$ (up to $3 \mathrm{~mL})^{2}$

Up until this date, the main argument for carrying out a general anesthesia over a regional anesthesia, in an emergent cesarian section, was the time-consuming preparation and the equipment needed for spinal anesthesia. However, since the beginning of the pandemic, all anesthesiologists are using an advanced personal protective equipment (PPE) regardless the positivity for COVID-19 and independently of the anesthetic modality used. So, 'equipment needed' disadvantage is no longer valid when facing pregnant women with suspected or confirmed COVID-19. For these reasons, the authors argue that the rapid sequence spinal technique should be seriously considered in category 1 emergency cesarian section in pregnant women with confirmed or suspected COVID-19. Regarding the placement of sterile gloves, we defend that they should be placed over the PPE in question. For rapid sequence spinal anesthesia to be carried out in an appropriate and safe way, it must be trained according to an institutional protocol elaborated, and meanwhile already published at institutional level, to guarantee the benefit that this technique can offer to these particular patients.

\section{Joana Santos Varandas, ${ }^{1}$ Raquel Dias, ${ }^{1}$ Angela Barbosa Mendes, ${ }^{1}$ Neusa Lages, ${ }^{1}$ Humberto Machado ${ }^{1,2}$ \\ ${ }^{1}$ Serviço de Anestesiologia, Centro Hospitalar Universitário do Porto, Porto, Portugal ${ }^{2}$ Instituto de Ciências Biomédicas Abel Salazar, Universidade do Porto, Porto, Portugal}

Correspondence to Joana Santos Varandas, Departamento de Anestesiologia Cuidados Intensivos e Emergência, Centro Hospitalar Universitário do
Porto, Porto 4099-001, Portugal; jsvarandas@gmail. com

Contributors All authors contributed equally in writing the letter.

Funding The authors have not declared a specific grant for this research from any funding agency in the public, commercial or not-for-profit sectors.

Competing interests None declared.

Patient consent for publication Not required.

Provenance and peer review Not commissioned; internally peer reviewed.

\section{(อ) OPEN ACCESS}

Open access This is an open access article distributed in accordance with the Creative Commons Attribution Non Commercial (CC BY-NC 4.0) license, which permits others to distribute, remix, adapt, build upon this work non-commercially, and license their derivative works on different terms, provided the original work is properly cited, an indication of whether changes were made, and the use is non-commercial. See: http:// creativecommons.org/licenses/by-nc/4.0/.

(C) American Society of Regional Anesthesia \& Pain Medicine 2021. Re-use permitted under CC BY-NC. No commercial re-use. Published by BMJ.

\section{Check for updates}

To cite Varandas JS, Dias $R$, Mendes $A B$, et al. Reg Anesth Pain Med 2021;46:191.

Received 16 April 2020

Revised 22 April 2020

Accepted 23 April 2020

Published Online First 6 May 2020

\section{SLinked}

- http://dx.doi.org/10.1136/rapm-2020-101725

Reg Anesth Pain Med 2021;46:191.

doi:10.1136/rapm-2020-101572

\section{REFERENCES}

1 Anaesthesia and caring for patients during the COVID-19 outbreak. Australian Society of Anaesthetists 2020

2 Kinsella SM, Girgirah K, Scrutton MJL. Rapid sequence spinal anaesthesia for category-1 urgency caesarean section: a case series. Anaesthesia 2010;65:664-9.

3 Kathirgamanathan A, Douglas MJ, Tyler J, et al. Speed of spinal vs general anaesthesia for category-1 caesarean section: a simulation and clinical observation-based study. Anaesthesia 2013;68:753-9. 